\title{
Rola światowego koncernu w przemianach przestrzeni przemysłowej Polski w okresie transformacji na przykładzie The Coca-Cola Company
}

Początek transformacji gospodarczej miał miejsce w Polsce na przełomie lat osiemdziesiątych i dziewięćdziesiątych XX w. Charakteryzował się dynamicznymi zmianami, których efektem końcowym było wprowadzenie gospodarki rynkowej. Wyraźna stabilizacja gospodarcza oraz szybkie wprowadzenie strefy wolnego rynku wzbudziły zainteresowanie światowych koncernów, rozważających ulokowanie swojej działalności produkcyjnej na terytorium Polski.

Przykładem koncernu o zasięgu globalnym, który w wyniku powyższych zmian podjął decyzję o uruchomieniu dystrybucji, a następnie produkcji była firma The CocaCola Company. Historia najbardziej rozpowszechnionej marki na świecie rozpoczęła się w Atlancie 8 maja 1886 r., kiedy aptekarz dr John Slyth Pemberton stworzył na bazie liści koki i orzechów koli zabarwiony karmelem syrop. Początkowa sprzedaż orzeźwiającego napoju nie była rentowna, jednak po przejęciu jej przez Asy Candlera, który w 1893 r. zarejestrował markę w amerykańskim Urzędzie Patentowym, dzięki sprawnym zabiegom marketingowym napój stał się rynkowym hitem, a zyski ze sprzedaży osiagnęły 5 mln USD już w 1912 r. W 1906 r. Coca-Cola oficjalnie przekroczyła granice Ameryki, uruchamiając proces butelkowania napoju w Kanadzie, Panamie i na Kubie, natomiast produkcja w rozlewniach europejskich (m.in. w Paryżu i Bordeaux) ruszyła w 1919 r. W tym samym roku udziałowcy Candlera sprzedali za 2,5 mln USD koncern bankierowi z Atlanty Ernestowi Woodruffowi i zorganizowanej przez niego grupie inwestorów. Nowy prezes przyjął strategię marketingową, dzięki której firma do dziś zajmuje czołową pozycję na rynku światowym. Najważniejszym elementem jego planu marketingowego było zapewnienie najwyższej jakości wytwarzanego produktu. W 1960 r. firma kupiła udziały Minute Maid Company, głównego sprzedawcy owoców cytrusowych w Ameryce, i poszerzyła swoją ofertę. Do dotychczasowych produktów dołączyły koncentraty mrożonych soków z owoców cytrusowych. W tym samym roku zastosowano również po raz pierwszy na świecie metalową puszkę jako opakowanie napoju. Obecnie firma jest największym na świecie producentem napojów bezalkoholowych, współpracującym z 1145 lokalnymi rozlewniami oraz 3500 hurtownikami i dystrybutorami na całym świecie, natomiast największa na świecie fabryka koncentratu Coca-Cola (TCCC) znajduje się w Puerto Rico.

Po raz pierwszy w Polsce Coca-Cola zaprezentowana została na Targach Poznańskich w 1957 r. W latach sześćdziesiątych dostępna była jedynie w sklepach sieci Pewex i Baltona, 
była wówczas synonimem luksusu i wolności. Przełomowym momentem okazał się rok 1971, kiedy to Edward Gierek doprowadził do negocjacji z koncernem The Coca-Cola Company, których wynikiem była umowa licencyjna na rozlewanie napojów na terenie Polski. 19 lipca 1972 r. rozpoczęto na zasadzie licencji realizowanej przez Polskie Zakłady Piwowarskie produkcję napoju w Warszawie. Równocześnie w Hucie Szkła w Wołominie uruchomiono linię produkcyjną butelek. W celu zaspokojenia dynamiczne rosnącego popytu na „nowy produkt” w 1973 r. uruchomione zostały dodatkowe linie produkcyjne w Tychach oraz Zabrzu, natomiast przewodnim hasłem marketingowym koncernu stał się slogan autorstwa Agnieszki Osieckiej „Coca-Cola to jest to!”.

Pierwszą bezpośrednią inwestycją koncernu The Coca-Cola Company w Polsce było uruchomienie w 1991 r. biura handlowego, mieszczącego się w Pałacu Kultury i Nauki w Warszawie i zatrudniającego w sumie 15 osób. Wówczas według badań marketingowych średnie roczne spożycie napojów z grupy Coca-Cola wynosiło jedynie 0,8 litra na jednego mieszkańca. Od tego czasu łączne inwestycje koncernu i autoryzowanych rozlewni przekroczyły 500 mln USD. W 2003 r. koncern The Coca-Cola Company stał się liderem na rynku polskim pod względem produkcji i sprzedaży napojów bezalkoholowych, a średnie roczne spożycie produkowanych napojów wzrosło do 12 litrów na jednego mieszkańca.

W każdym z 200 krajów na świecie, w tym również w Polsce, firma The Coca-Cola Company działa na zasadzie systemu, składającego się z firmy reprezentującej właściciela marki oraz lokalnych rozlewców, którzy odpowiedzialni są za produkcję i dystrybucję napojów. Współpraca pomiędzy powyższymi podmiotami opiera się na ugruntowanym partnerstwie i wzajemnych relacjach biznesowych. W Polsce firma The Coca-Cola Company podzielona jest na dwa podmioty gospodarcze: Coca-Cola Poland Services Sp. z o.o. oraz Coca-Cola HBC Polska Sp. z o.o., zatrudniające łącznie ponad 3500 pracowników. Pierwszy z powyższych podmiotów reprezentuje markę, a jego działalność skupia się przede wszystkim na działaniach marketingowych, do których można zaliczyć: reklamę produktów i kontakt z mediami, wdrażanie nowych produktów, promocje konsumenckie i inne. Natomiast lokalny rozlewca, czyli Coca-Cola HBC Polska Sp. z o.o., odpowiedzialny jest za działania produkcyjne i dystrybucyjne (centra produkcyjne, sprzedaż i dystrybucję produktu, obsługę klienta, wyposażenie punktów sprzedaży w sprzęt chłodniczy, promocje konsumenckie, lokalne działania $\mathrm{i}$ inne).

Obecnie główna siedziba firmy znajduje się w warszawskiej dzielnicy Białołęka, natomiast trzy nowoczesne zakłady produkcyjne zlokalizowane są w Radzyminie koło Warszawy, Staniątkach koło Niepołomic oraz Łodzi. Ponadto w skład koncernu wchodzi rozlewnia wody butelkowanej w Tyliczu. Najstarszy, oddany do użytku w 1992 r. i zarazem największy zakład produkcyjny mieści się w Radzyminie. Następnie uruchomiono zakład produkcyjny w Łodzi (1995 r.), natomiast produkcja w kolejnych dwóch została rozpoczęta w 1998 r. Pod względem ilości zakładów produkcyjnych w Europie Polska zajmuje 7 miejsce za Francją (15), Niemcami (12), Wielką Brytanią (10), Włochami (7), Rosją (6) oraz Irlandią i Hiszpanią (5).

Analizując strukturę zatrudnienia firmy The Coca-Cola Company, należy zauważyć, iż od 1991 r. liczba pracowników stale wzrasta. Jest to wynikiem konsekwentnego zwiększania produkcji oraz otwierania nowych oddziałów. W 2000 r. (przy funkcjonowaniu czterech zakładów produkcyjnych) w firmie pracowało 2217 pracowników, co stanowiło 62\% ogółu obecnie zatrudnionych. Pięć lat później zatrudniano już 3038 osób (85\% ogółu zatrudnionych obecnie). W 2009 r. we wszystkich działach zatrudnionych było 3572 pracowników. 
Dynamika zmian liczby zatrudnienia była największa w latach 2000-2005, co było odzwierciedleniem gwałtownego rozwoju firmy na rynku polskim. Należy również zauważyć, że w okresie od uruchomienia produkcji w poszczególnych zakładach do 2009 r. liczba zatrudnionych wzrosła średnio o 288\% (Radzymin - 353\%, Tylicz - 303\%, Staniątki - 273\%, Łódź - 221\%). Obecnie najwięcej zatrudnionych jest w dziale sprzedaży oraz zakładach produkcyjnych w Radzyminie i Łodzi. Szczegółowe dane dotyczące zatrudnienia wraz podziałem na główne działy firmy zawarte zostały w tab. 1.

Tab. 1. Zmiana wielkości zatrudnienia w latach 1992-2009

\begin{tabular}{|l|r|r|r|r|}
\hline \multicolumn{1}{|c|}{ Dział } & 1992 lub * & 2000 & 2005 & 2009 \\
\hline Zakład produkcyjny Radzymin & 202 & 580 & 632 & 714 \\
\hline Zakład produkcyjny Staniątki & $180(1998)$ & 205 & 420 & 493 \\
\hline Zakład produkcyjny Tylicz & $56(1998)$ & 88 & 144 & 171 \\
\hline Dział sprzedaży & 65 & 529 & 805 & 980 \\
\hline $\begin{array}{l}\text { Dział logistyki i transportu } \\
\text { (bez zew. firm spedycyjnych) }\end{array}$ & 30 & 85 & 110 & 165 \\
\hline Dział finansowy & 15 & 61 & 95 & 135 \\
\hline Dział marketingu & 10 & 25 & 32 & 59 \\
\hline Pozostałe działy & brak danych & 225 & 290 & 310 \\
\hline OGÓŁEM: & - & 2217 & 3038 & 3572 \\
\hline
\end{tabular}

* rok uruchomienia zakładu produkcyjnego

Źródło: materiały wewnętrzne firmy The Coca-Cola Co.

Sieć dystrybucji i sprzedaży firmy The Coca-Cola Company zaliczana jest do najbardziej rozbudowanych na rynku polskim. W 35 lokalnych centrach sprzedaży, zlokalizowanych najczęściej w największych miastach subregionów (ryc. 1), pracuje łącznie około 980 specjalistów ds. rozwoju rynku i obsługi klientów. Sieć magazynów firmy składa się z czterech magazynów operacyjnych (przyfabrycznych) zlokalizowanych w bezpośrednim sąsiedztwie zakładów produkcyjnych, magazynów depotowych (dystrybucyjnych) zlokalizowanych w większych centrach sprzedaży (np. Warszawa, Poznań, Gdynia, Szczecin, Wrocław, Mysłowice, Lublin) oraz X-docków (Crossdocków), czyli magazynów bez zapasu, będących jedynie miejscem przeładunku towaru dostarczonego z fabryki na ciężarówki realizujące dostawy bezpośrednio do klientów. Dzienna wymiana produktów pomiędzy siecią magazynów i realizacja dostaw dla odbiorców wykonywana jest za pośrednictwem 320 samochodów TIR oraz 830 ciężarówek.

Warto podkreślić, iż w okresie 17 lat funkcjonowania firmy na rynku polskim wielkość produkcji dla rynku krajowego charakteryzowała się trendem wzrostowym (ryc. 2). Największa dynamika zmian wielkości produkcji przypadła na okres 1995-2000, co było związane z uruchomieniem trzech nowych zakładów produkcyjnych i wprowadzeniem do sprzedaży nowych produktów. Wielkość produkcji w 2009 r. wyniosła 765 mln litrów, co oznacza wzrost o 2013\% (tj. o 727 mln litrów) w stosunku do wielkości produkcji początkowej z 1992 r., która kształtowała się na poziomie 38 mln litrów. Powyższe wartości znajdują odzwierciedlenie w przypadku charakterystyki spożycia napojów z grupy Coca-Cola Company przez jednego mieszkańca Polski w skali roku. W 1992 r. wynosiło ono zaledwie 
1,0 litra, obecnie 19,0 litrów. Przy badaniach udziałów w rynku napojów bezalkoholowych produkty wytworzone w zakładach produkcyjnych Coca-Cola Company w Polsce liczyły odpowiednio: 4\% (1992 r.), 40\% (2000 r.), 52\% (2005 r.), 68\% (2009 r.). Analizując prognozy sprzedażowe na kolejne lata, należy stwierdzić dalszy wzrost produkcji i sprzedaży napojów z grupy Coca-Cola Company, jednak o zdecydowanie niższej dynamice niż w latach poprzednich. W najbliższych latach nie planuje firma uruchomienia kolejnego zakładu produkcyjnego, a poniesione inwestycje nie będą na tak wysokim poziomie, jak dotychczas.

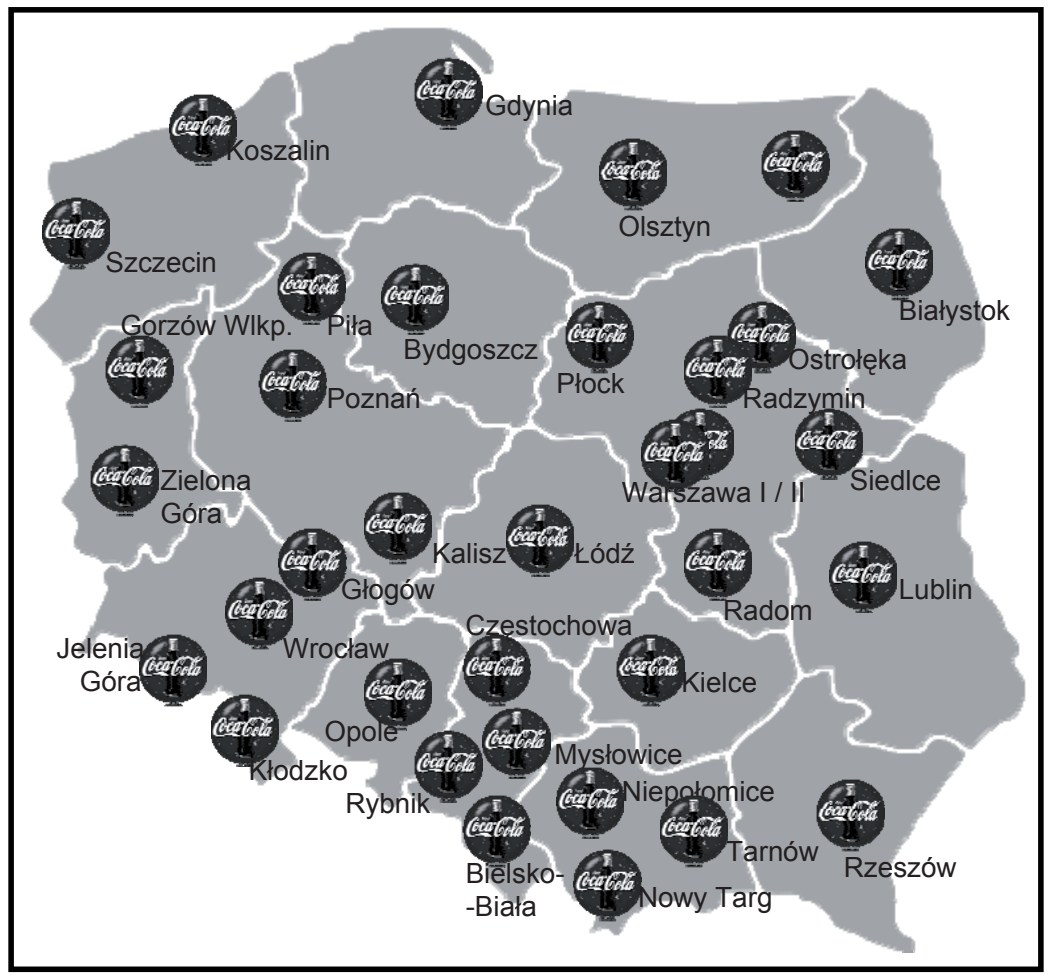

Ryc. 1. Sieć sprzedaży firmy The Coca-Cola Company w Polsce

Źródło: opracowanie własne na podstawie materiałów wewnętrznych firmy The Coca-Cola Co.

Wśród marek firmy obecnych na rynku polskim wymienić należy: Coca-Cola, CocaCola Zero, Coca-Cola Light, Cherry Coke, Fanta, Sprite, Lift, Kinley Tonic, napój izotoniczny Powerade, soki, nektary i napoje owocowe Cappy, napój energetyczny Burn, napoje herbaciane Nestea, napoje kawowe Illy oraz naturalna woda źródlana Kropla Beskidu i woda mineralna Vita Kropla Minerałów. Analizując rodzaj opakowań produktów należy stwierdzić, iż największy udział mają opakowania plastikowe (47\% ogółu), kolejno butelki szklane (22\% ogółu) i puszki ( $21 \%$ ogółu). 


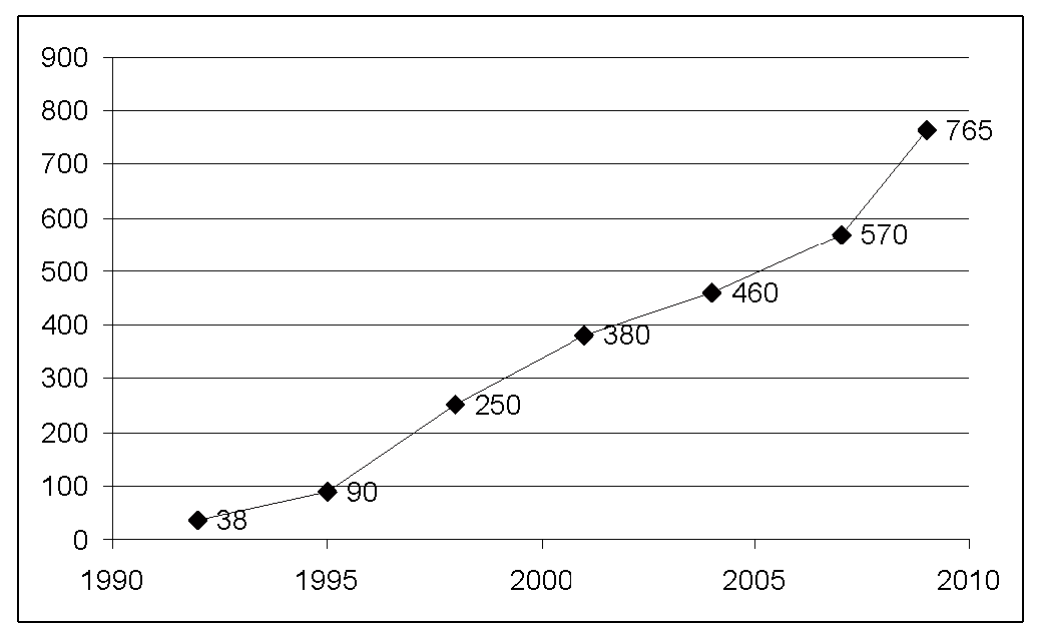

Ryc. 2. Wielkość produkcji firmy The Coca-Cola Co. w Polsce w okresie 1992-2009 (w mln litrów)

Źródło: opracowanie własne na podstawie materiałów wewnętrznych firmy The Coca-Cola Co

Analizując sieć zakładów produkcyjnych, przedsiębiorstw powiązanych z procesem produkcji oraz sieć głównych odbiorców, należy stwierdzić, że powstał klaster wytwórczy, czyli tzw. grono przemysłowe. Według definicji M. E. Portera (2001), jest to występujące na danym obszarze skupisko wzajemnie powiązanych, wyspecjalizowanych w danej dziedzinie produkcji oraz konkurencyjnych firm i instytucji, działających w tych samych lub pokrewnych sektorach gospodarki. Są to więc zarówno firmy produkcyjne, dostawcy surowców i materiałów pomocniczych, producenci maszyn, narzędzi i pozostałych komponentów, jak również firmy serwisowe i dostawcze oraz ośrodki naukowo-badawcze i inne organizacje branżowe (Wieloński 2007).

W przypadku grona przemysłowego firmy The Coca-Cola Company w Polsce należy zauważyć dominację dwóch grup zakładów produkcyjnych, oznaczonych na ryc. 3 logotypami wytwarzanych produktów. Pierwszą z nich stanową cztery zakłady produkcyjne zlokalizowane na obszarze Polski, natomiast drugą - zakłady produkcyjne zlokalizowane na obszarze Czech, Słowacji, Węgier i Włoch wytwarzające bardziej wyspecjalizowane produkty: tj. Kinley Tonic, napój izotoniczny Powerade, napój energetyczny Burn, napoje herbaciane Nestea oraz napoje kawowe Illy. Ponadto ważnym ogniwem są podmioty odpowiedzialne za opakowanie produktu oraz urządzenia produkcyjno-techniczne. W przypadku tych pierwszych (produkcja opakowań plastikowych i szklanych, etykiet, kapsli i nakrętek oraz puszek) w większości są to przedsiębiorstwa krajowe, natomiast zapleczem technologicznym zajmuję się wyspecjalizowane firmy niemieckie, brytyjskie oraz amerykańskie. Powyższe grono tworzy również zaplecze naukowo-badawcze, stanowiące zespół laboratoriów zlokalizowanych przy każdym zakładzie produkcyjnym, a także dział marketingowy, public relations, logistyczny i transportowy. Odrębną jednostką jest podmiot odpowiedzialny za import koncentratu TCCC, będącego podstawowym składnikiem napojów gazowanych, tj. CocaCola, Fanta, Sprite i Lift, oraz komórka handlowa zajmująca się eksportem wytworzonych w łódzkiej fabryce soków, nektarów i napojów owocowych Cappy. Najważniejszym jednak 
elementem opisywanego grona są odbiorcy, czyli narodowe i ogólnopolskie sieci handlowe oraz pozostałe jednostki detaliczne, umożliwiające dotarcie produktów do konsumentów.

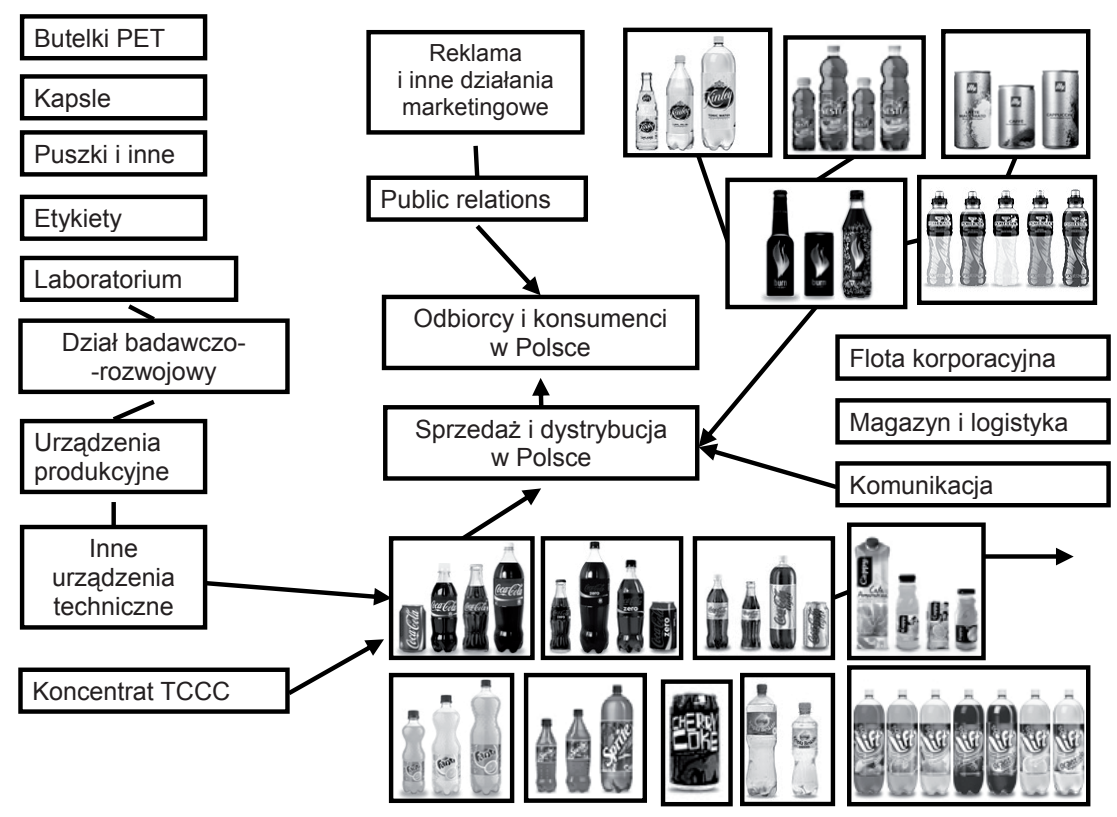

Rys. 3. Grono przemysłowe The Coca-Cola Company

Źródło: opracowanie własne na podstawie materiałów wewnętrznych firmy The Coca-Cola Co

Konkludując, należy zauważyć, iż charakteryzowany koncern w ciągu niespełna dwóch dekad stał się czołowym producentem i dystrybutorem napojów bezalkoholowych w Polsce. Począwszy od 15-osobowego biura handlowego, dzięki licznym inwestycjom i wdrożeniom nowoczesnych technologii doprowadził do dynamicznych zmian w sektorze przemysłu spożywczego, jak również zaznaczył się w tworzeniu obecnej przestrzeni gospodarczej Polski. Ponadto uruchomienie kolejnych zakładów produkcyjnych przyczyniło się do zmniejszenia stopy bezrobocia w obszarach przyległych do miejscowości, w których znajdują się ośrodki produkcyjne firmy. Należy również wspomnieć o społecznej roli koncernu The Coca-Cola Company, przejawiającej się w działalności charytatywnej, propagowaniu aktywnego stylu życia, działaniach proekologicznych oraz wspieraniu rozwoju kultury, sztuki i nauki.

Wypada też wspomnieć, iż według światowej strategii firmy, nadrzędnym jej celem jest utworzenie międzynarodowego zespołu, który sprawi, by największa światowa marka stała się również marką globalną. Patrząc na powyższe stwierdzenie z punktu zakładów produkcyjnych w Polsce, należy stwierdzić, że jest ono w dużej mierze realizowane, a dalszy rozwój firmy może prowadzić do kolejnych zmian w przestrzeni gospodarczej kraju. 


\section{Literatura}

Nasiłowski M., 1995, System rynkowy: Podstawy mikro- i makroekonomii, Instytut Ekonomiczny PTE, Warszawa.

Porter M.E., 2001, Porter o konkurencji, Polskie Wydawnictwo Ekonomiczne, Warszawa.

Wieloński A., 2007, Teoretyczne podstawy lokalizacji działalności gospodarczej, Uniwersytet Warszawski, Wydział Geografii i Studiów Regionalnych, Warszawa.

Materiały wewnętrzne The Coca-Cola Company Polska http://www.cocacola.com.pl

\section{Role of a world-wide company in changes of industrial space of Poland in the transformation period, with special reference to the Coca-Cola Company}

The Coca-Cola Company, a producer of soft drinks, the largest in the world and also in Poland, started its production in Poland in 1992. The first factory was based in Radzymin near Warsaw and in the beginning it employed 200 workers. It was the first direct investment of the Company, which initiated subsequent investments connected with setting up new factories and gradual development of distribution network. At present, in the Polish market the Coca-Cola Company employs over 3500 workers and owns three modern factories located in Staniątki near Niepołomice, Łódź and Radzymin, and also a bottling plant in Tylicz. Moreover, its distribution and sale network is recognized as one of the most advanced in the Polish market. About 980 market and sale specialists are employed in 35 local sale centres, situated in the largest towns of the subregions. As a result of its investments and financial expenditures during the last two decades, the Coca-Cola Company has significantly influenced the employment structure, and simultaneously, it has become a significant element of food industry in Poland. A key strategy and the primary aim of the Company is creation of an international team which would let the largest world-wide brand become a global brand. Taking into account this assumption and the performance of the Coca-Cola Company in the Polish market, it may be assumed that the aim of the Company is accomplished and its further development may result in further changes in the economic space of Poland.

prof. UŚ dr hab. Maria Tkocz

Uniwersytet Śląski w Katowicach

Katedra Geografii Ekonomicznej

Zakład Gospodarki Przestrzennej

mgr Jakub Żydzik

Uniwersytet Śląski w Katowicach

Katedra Geografii Ekonomicznej

Zakład Gospodarki Przestrzennej 